\title{
Private and Public Devotion in Late Renaissance Italy: The Role of Church Censorship
}

\author{
Giorgio Caravale
}

Despite the differences in their respective traditions, from the thirteenth century onwards, Franciscan and then Dominican spirituality placed the notion of inward prayer at the heart of their religious discourses. Following St Francis, both St Clare and St Anthony located 'the foundation of contemplative life in the spirit of prayer', while St Bonaventure noted that 'perfect prayer' was a fundamental stage in the mystical ascent towards God. ${ }^{1}$ In the fourteenth century, the Dominicans - especially Domenico Cavalca - developed Thomas Aquinas' concept of the spirit, understanding mental prayer as the essence of the contemplative practice of mystical asceticism. Later, Catherine of Siena pronounced that humble, continuous, faithful and disinterested prayer was the instrument through which the soul acquires all virtue,', ${ }^{2}$ asserting the superiority of mental prayer over spoken prayer. The rich medieval tradition of mental prayer survived throughout the fifteenth century in the thought of great spiritual authorities, such as St Antonino and Ludovico Barbo, until the turn of the sixteenth century when it found its most efficacious expression in the thought of Savonarola. ${ }^{3}$

Savonarola's defence of mental prayer not only acknowledges the superiority of mental prayer over spoken prayer, but explicitly criticises devotion that is outwardly expressed. ${ }^{4}$ According to Savonarola, and many other critics of the Roman Curia, public devotion encouraged mechanical recitation over profound spiritual reflection. Spoken prayer, and public ceremonies more generally, should instead recover their original functions as stimuli and

1 Heerinckx J., "Les sources de la théologie mystique de S. Antoine de Padoue", Revue d'ascétique et de mystiques 13 (1932) 225-256; Heerinckx J., "La mistica di S. Antonio da Padova", Studifrancescani 5 (1933) 39-6o.

2 Caterina da Siena, Le lettere, ed. N. Tommaseo, vol. II (Florence: 186o) 416-418.

3 For an introduction to these topics, see Petrocchi M., Storia della spiritualità italiana, vol. I: Il Duecento, il Trecento e il Quattrocento (Rome: 1978). See also Getto G., Letteratura religiosa dal Duecento al Novecento (Florence: 1967) and Getto G., Letteratura religiosa del Trecento (Florence: 1967).

4 See Dall'Aglio's essay in this volume, 383 .

(C) GIORGIO CARAVALE, 2019 | DOI:10.1163/9789004375871_018

This is an open access chapter distributed under the terms of the prevailing CC-BY-NC-ND License at the time of publication. 
intermediary steps in mankind's passage to God. The faithful should abandon simply chanting them more or less unconsciously throughout the course of the day. ${ }^{5}$ This requirement was not only expressed by bitter critics of Rome, such as Savonarola, but was also evident in the treatises of important Church clerics, such as Paolo Giustiniani and Pietro Querini. ${ }^{6}$

Like Martin Luther and others who will be considered shortly, these authors used the term 'private' as a synonym of 'mental'. Prayers recited deep in the conscience - the result of an inner dialogue with God - were defined as 'private' in contrast to spoken prayer, which was also often regarded as 'public'. As the decades passed, these two terms ('public' and 'private') acquired a broader and more cogent meaning. Above all, in the ecclesiastical sources under consideration, the term 'private' refers to all acts of worship performed away from an audience of the faithful, therefore including prayers recited silently and internally in a public place, prayers recited aloud in the privacy of the home and prayers used 'privately' by a confraternity or local religious brotherhood. Instead, the designation 'public' encompassed everything shared with an audience of believers - regardless of its size - on official liturgical occasions.

Martin Luther's work on private devotion and mental prayer forms part of such a line of thought and takes up many of the themes proposed by Savonarola. His discussion inevitably changed the terms of debate. In his $A n$ Exposition of the Lord's Prayer for Simple Laymen, Luther, like Savonarola, is careful not to disapprove of spoken prayer, but feels that trust is excessively placed in prayers that are verbally expressed. For Luther, as for Savonarola, spoken prayer is a necessary tool for preparing the soul for the inner dialogue with God, which he calls 'the meditation of the heart'. ${ }^{7}$ However, when Luther moves from a general reflection on the Lord's Prayer to a detailed analysis of its particular sections, the unmistakable finality of his vision of predestination emerges, and thus marks a clear break from the works by Savonarola. In

5 Savonarola expressed these positions most firmly in two works published in 1492: Trattato in difensione e commendazione dell'orazione mentale and Trattato o vero sermone dell'orazione, both printed in Florence by Miscomini. Modern versions of these works can been found in Savonarola Girolamo, Operette spirituali, ed. M. Ferrara, vol. I (Rome: 1976) 157-185 and 189224 respectively. See also the discussion by Ferrara, 385-407.

6 Mittarelli Johannes Benedictus - Costadoni Anselmus, Annales Camaldulenses Ordinis Sancti Benedicti quibus plura interseruntur tum ceteras Italico-monasticas res, tum historiam ecclesiasticam remque diplomaticam illus (Venetiis, Pasquali Giambattista: 1755-1773), tome IX (1773) fols. 612-719. For a recent Italian translation, see: Lettera al Papa. Paolo Giustiniani e Pietro Quirini a Leone X, ed. G. Bianchini, introduction by F. Cardini (Modena: 1995).

7 Luther Martin, An Exposition of the Lord's Prayer for Simple Laymen, in Luther's Works, American Edition, (Saint Louis - Philadelphia: 1955-), vol. 42: Devotional Writings, I, ed. M.O. Dietrich (Philadelphia: 1969) 19-81. 
Luther's interpretation, each section is characterised by a constant recalling of the misery of human nature and an unmistakable invitation to submit one's self to the grace of God, in a pattern that encourages self-denigration and the subsequent exaltation of divine power. ${ }^{8}$

The debate on these themes that developed in the Italian peninsula in the following decades inevitably felt the shock of the religious rift resulting from the Lutheran challenge to Rome. Although Luther did not reject all Roman devotional trappings, by retaining, for instance, the usefulness of 'St Bridget's Fifteen Prayers, rosaries, the crown prayers, the Psalter, etc.,' ${ }^{9}$ he insisted on the supremacy of the Lord's Prayer over all other prayers. ${ }^{10}$ The insistence on a single prayer was taken up and, in many respects, taken to the extreme as a sign of the strong anti-Roman militancy of those in the Italian peninsula who chose to follow in Luther's tracks. Many of Luther's Italian followers declared the supremacy of the Lord's Prayer in terms of its exclusivity as the Sunday prayer, as the only legitimate prayer for good Christians. ${ }^{11}$ The 1530 s witnessed a proliferation of Espositioni del Pater noster, commentaries on the Sunday prayer, which also took up the idea of the exclusivity and superiority of the Lord's Prayer over other devotional prayers with varying degrees of explicitness. ${ }^{12}$ This represented a potential threat to the devotional system, which was based on the recitation of a high number of prayers, each repeated at specific times of the day as part of a detailed system of sanctioned spiritual practice. Rome could not remain indifferent to this challenge. By 1547, the Lord's Prayer had been clearly identified as a favourite target of repressive action aimed at exposing all the secret codes used by heterodox Italians. 'This heresy begins with the Our Father and ends with the pike and musket', wrote Alvise Lippomano in 1547 to Cardinal Marcello Cervini, the future Pope Marcellus II. ${ }^{13}$ The 1559 Pauline

\footnotetext{
$8 \quad$ Ibid., $35-43$.

9 Ibid., 25 .

$10 \quad$ Ibid., 21.

11 Caravale G., Forbidden Prayer: Church, Censorship and Devotional Literature in Renaissance Italy (Farnham: 2011) 23-24.

12 Savonarola was among the first to write a commentary on the Lord's Prayer, see Espositione sul Pater noster (Florence: 1494), translated from a version in a Latin manuscript, which was then published a few years later (Expositio orationis dominicae [Florence, Tubini: 1500]). This text can also be found in Savonarola, Operette spirituali 225-277. On the text by Savonarola, see also Prosperi A., "Les commentaires du Pater noster entre les XV et XVI siècles", in Aux origines du catéchisme en France (Paris: 1989) 87-105, especially 89.

13 Letter from Bologna, 16th November 1547, quoted by Prosperi A., "Preghiere di eretici. Stancaro, Curione e il Pater Noster", in Erbe M. - Fuglister H. - Furrer K. - Staehelin A. Wecker R. - Windler C. (eds.), Querdenken. Dissens und Toleranz im Kandel der Geschichte. Festschrift zum 65. Geburtstag von Hans R. Guggisberg (Mannheim: 1996) 203-221 (216),
} 
Index, the first official Roman list of prohibited books, took up this suggestion and transformed it into a concrete measure for censorship. Savonarola's works on mental prayer are listed in the index alongside the anonymous Espositione dell'oratione del Signore in volgare, composta per un padre non nominato, a vernacular commentary on the prayer composed for an unnamed father. ${ }^{14}$ It is possible that Roman inquisitors intended to target a specific work with this ban, one of the many anonymous works that circulated in the Italian peninsula at that time..$^{15}$ However, the general nature of the ban suggests that the inquisitors intended to sanction an entire literary genre, which had been hostage to Italian religious dissidence.

The novelty of this type of Espositioni was not limited to the insistence on the primacy and exclusivity of the Lord's Prayer. In the 1530 s and 1540s, the distinction between spoken prayer and mental prayer, discussed by Savonarola and Luther in a polemical anti-Roman manner, gradually transformed into a distinction between public and private spheres of devotion. This represented an artificial overlap of two distinct sets of ideas, as opposed to a true reflection of the reality. As noted, the habit of mechanical recitation could characterise both private and public life. A woman could 'mumble Our Fathers' indifferently in the middle of a public ceremony as well as when she was busily attending to her household duties. In other words, prayers could be spoken out loud in public places, such as in churches and town squares, as well as in the privacy of

edited by Buschbell G., Reformation und Inquisition in Italien um die Mitte des XVI Jahrhunderts (Padeborn: 1910) 289-290.

14 The Index of $155^{8}$ prohibited many of Savonarola's sermons and homilies. The ban was tempered by the clause quamdiu expurgantur in the Tridentine Index; cf. Index des livres interdits, vol. viII: De Bujanda J.M. (ed.), Index de Rome 1557, 1559, 1564. Les premiers index romains et l'index du Concile de Trente (Sherbrooke - Geneva: 1990) 501-505. For the censorship of Savonarola's works, see Fragnito, G., "La censura ecclesiastica e Girolamo Savonarola", Rivista di Storia e Letteratura Religiosa 35 (1999) 501-529, and Rozzo U., "Savonarola nell'Indice dei libri proibiti", in Fragnito G. - Miegge M. (eds.), Girolamo Savonarola: da Ferrara all'Europa (Florence: 2001) 239-268. The anonymous Espositione appeared in the Venice Indices as early as 1549 and 1554; see De Bujanda J.M. (ed.), Index des livres interdits, vol. III: Index de Venise, 1549, Venise et Milan, 1554 (Geneva: 1987) respectively 203-224 and 271 and also remained in the unpromulgated 1590 and 1593 Indices; see De Bujanda J.M. et alii (eds.), Index des livres interdits, vol. Ix: Index de Rome 1590, 1593, 1596 (Geneva: 1994) 433. On the Pauline and Tridentine Indices, see Index des livres interdits, vol. viII, 258-259. The Dominicae precationis explicatio, printed Lugduni, by Gryphum and alios was also banned; cf. Index des livres interdits, vol. viII, 484-485, 638,660 . On these themes, see also Rozzo U., "La cultura italiana nelle edizioni lionesi di S. Gryphe (1531-1541)", La Bibliofilia 90 (1988) 161-195.

15 Despite the slight difference in the title, it is possible that the text was written by Francesco Stancaro, who is cited in the following note (note 16). 
one's own home. Similarly, although there was a preference for practising mental prayer within the walls of the home, there was nothing to stop the practice inside churches or even on noisy city streets. What contributed to this conceptual, and indeed semantic, overlap was the intensification of religious clashes in the Italian peninsula between those who sought to defend and disseminate Protestant doctrine at all costs and those who sought to prevent every such manifestation of religious dissent with strong repression. The polarisation that resulted from these religious clashes led heterodox Italians to use the public/ private dialectic with increasing anti-Roman intent. These heterodox Italians upheld the private sphere as the only possible place in which they could continue exercising genuine personal religious devotion, the only possible answer to the hypocrisy of the external religious conformity that the Roman authorities demanded by force.

The clear preference for personal and private prayer as an interior refuge from outside conformist pressures is evident, for instance, in the reflections of thinkers such as Francesco Stancaro and Simone Porzio. Developing their writing along the lines of Luther's thought, they emphasised that personal and private prayer was undoubtedly the form of devotion most highly esteemed by God. In their view, interior meditation required mental isolation from the hustle and bustle of public life. ${ }^{16}$ Only such meditation could guarantee profound detachment from the routine of daily life, and from earthly ties in general, that obstruct direct dialogue with God. Stancaro's and Porzio's 'camera serrata', or locked chamber, was the chamber of the heart, that most hidden part of the soul on which the faithful must meditate to participate in a fruitful conversation with God. It was preferable (although not necessary) to link this secret hidden chamber to a private physical location in which, once the door had been 'closed', one could 'pray secretly to the father'. Identifying a secret place away from prying eyes, it is possible to interpret these lines written at the end of the 1530 as anveying the need to protect one's privacy from the far-reaching gaze of the inquisitorial authorities.

16 The works referred to are: Espositione utilima sopra il Pater noster, con duoi devotissimi trattati, uno in che modo Dio esaudisce le orationi nostre, l'altro di penitentia (Venice, s.n.: 1539) attributed to Francesco Stancaro (see below), and Porzio Simone, Christianae deprecationis interpretatio (1538), translated and published in Italian in 1551 by Giovanbattista Gelli under the title of Modo di orare christianamente con la espositione del Pater noster, fatta da M. Simone Portio Napoletano. Tradotto in lingua Fiorentina, da Giovan Batista Gelli (in Fiorenza, Lorenzo Torrentino: 1551), eventually republished the following year (1552) in Latin in a modified edition; cf. Del Soldato E., Simone Porzio. Un aristotelico tra natura e grazia (Rome: 2010) 135-137. 
A few years later, Francesco Stancaro fled to Switzerland where he professed his reformed beliefs freely. In Switzerland, Stancaro then returned to the first Italian version of the Espositione, published anonymously in Venice in 1539, and submitted it for publication alongside other texts in Basel in 1547. This time he published the commentary on the Lord's Prayer with greater freedom than in the first Italian version a few years earlier. Stancaro censored specific details about Italian life, which from his exile in Switzerland might have seemed unnecessary and distant, and of little interest to Protestant readers in Switzerland. ${ }^{17}$ Simone Porzio, on the other hand, remained in the Italian peninsula seeking to reach a compromise between his Erasmian and Valdesian religious training, his philosophical Hermeticism and the requirements of Tridentine orthodoxy. The new version of his Latin work on the Lord's Prayer published in $155^{2}$ is testimony to this effort of reconciliation. It was more than just a series of literary and formal revisions that transformed the Interpretatio into the Enarratio. To give just one example, the exaltation of the salvific selfsufficiency of faith that characterises the first version is modified in the second version by the statement that one cannot obtain the heavenly riches of the blessed through one's faith alone but also, and above all, through good works. ${ }^{18}$ These two different choices, indeed opposing choices I would say, shared, at least at this time, a common Nicodemistic matrix. In these writings, the invitation to pursue a renewed inner piety, to create a mental and physical space in which to cultivate the essence of one's own faith, became a characteristic of Nicodemism, even if the authors never theorised on their religious choices using this term.

In the first half of the sixteenth century, there was an increasingly strong connection between inner piety and mental prayer on the one hand, and heterodox inclinations (thinly veiled by Nicodemistic attitudes) on the other, which influenced the attitude of Roman authorities in devotional matters. Defenders of Catholic orthodoxy developed a certain degree of diffidence, if not open hostility, towards the crypto-Protestant position. Consequently, in the following decades Counter-Reformation religiosity characterised itself by a preference for open displays of piety, performed publicly, often sung, but in all instances practised collectively, within Church walls or in the open spaces

17 Prosperi, "Preghiere di eretici" $5^{0-52 .}$

18 As a precautionary measure, the work was dedicated to Cardinal Alvarez de Toledo, inquisitor and relative of Pedro de Toledo. On this process of rewriting, see Del Soldato, Simone Porzio 145-147; Del Soldato E., "La preghiera di un alessandrinista: i Commenti al Pater di Simone Porzio", Rinascimento 46 (2006) 53-71. 
of popular missions. ${ }^{19}$ For Rome, chanting, and the collective performance of prayer more generally, was the preferred method of regulating the spiritual life of worshippers who were not always culturally and doctrinally well-informed. The most famous work of Carlo Borromeo, the leading figure of the CounterReformation, is his Lettera pastorale e istituto dell'orazione comune (1572). In this work, it is the collective dimension of prayer that the Archbishop of Milan upholds, the dimension that is 'able to ingrain an extraordinary force on one's mind,' 'that holy prayer', 'the need of which is common to all'. ${ }^{20}$

However, despite this preference for the collective and communal dimension of devotion, the Counter-Reformation Church was not prepared to renounce individual prayer or the private dimension of devotion more generally. Not only was this because private devotion was rooted in a rich and centuriesold theological tradition, as mentioned at the start of this essay, but some of the most intense manifestations of Catholic devotion were expressed through this channel. Private devotion had a fundamental role in the spiritual life of worshippers. It was therefore regulated as much as possible, but not demonised. Only after the central decades of the sixteenth century, after the height of the anti-Protestant battle and after the eradication of the danger of Protestant heresy in the Italian peninsula, did Rome, in the final decades of the sixteenth century, devote most of its energy to reviving the tradition of interior and private spaces of devotion. Rome did not, of course, stop intervening in areas that risked encouraging practices as dangerous as the Lutheran message. The new danger was perceived to have two diametrically opposed positions: the aristocratic (and clerical) position of mysticism and the popular position of superstitious devotional practice. Within the confinement of convent cells or concealed behind the walls of stately homes, it was not uncommon for inner meditation through prayer to take the form of an intense devotional fervour. Severing earthly ties and collapsing institutional and Church barriers, such intense fervour led to the total abandonment of one's self in mystical union with God and a state of spiritual intoxication often associated with impeccable purity. ${ }^{21}$ Conversely, in more modest city or country homes, the intimacy of

19 Prosperi A., Tribunali della coscienza. Inquisitori, confessori, missionari (Turin: 1996), esp. part III.

20 'capace di imprimerle una forza straordinaria', 'questa santa orazione' of which 'il bisogno è a tutti comune'. See Di Filippo Bareggi C., "Libri e letture nella Milano di San Carlo Borromeo", in Raponi N. - Turchini A. (eds.), Stampa, libri e letture a Milano nell'età di Carlo Borromeo (Milan: 1992) 39-96, esp. 89; Caravale, Forbidden Prayer 90.

21 Among the texts in the rich bibliography on this topic, see Novi Chavarria E., Monache e gentildonne: un labile confine. Poteri politici e identità religiose nei monasteri napoletani: secoli XVI-XVII (Milan: 2001); Jacobson Schutte A., Aspiring Saints: Pretense 
the domestic space could lead to superstitious rituals surrounding objects and words, which attributed magical powers to the repetition of pre-printed formulas or the enactment of specific bodily gestures. ${ }^{22}$ Catholic orthodoxy was thus threatened on two fronts: by excessive focus on the inner life and by the excessive misuse of outward signs.

Church censorship and the Roman Inquisition played important roles in the post-Tridentine decades in trying to restrain these opposing devotional excesses. On the one hand, the spiritual fathers, noble ladies and passionate abbesses who trespassed over the fine line separating orthodoxy from heresy with their mystical experiences were put on trial by Rome without hesitation. ${ }^{23}$ The work of the Inquisition was accompanied by censorship that controlled all texts that manifested evidence of these experiences. Censorship aimed to erase the margins of human free will, watering down its role in the state of sinlessness resulting from mystical union with God. ${ }^{24}$ On the other hand, censors and inquisitors created a series of prohibitions aimed at identifying and isolating sources of devotional superstition. For instance, these attacked the use of rubrics, formulas composed of a few words that preceded or concluded a prayer and informed the worshipper of the most effective way to recite the text. Or they listed titles of superstitious prayers that should be banned from the prescribed repertoire of a devout Catholic. ${ }^{25}$

Over the course of the following decades, this dual process of control and repression, aimed at both high and low, became increasingly difficult to implement. The first reason for this was that these censorial measures had been

of Holiness, Inquisition, and Gender in the Republic of Venice, 1618-1750 (Baltimore, Md.: 2001); Sluhovsky M., Believe Not Every Spirit: Possession, Mysticism, \& Discernment in Early Modern Catholicism (Chicago: 2007).

22 Recent scholarship has however demonstrated that this dichotomy is more complicated than it was supposed. On the 'elusive and slippery term' of superstition, especially explored from the point of view of 'theologically educated people', see now the important work by Cameron E., Enchanted Europe: Superstition, Reason, and Religion 1250-1750 (Oxford: 2010). A good selection of relevant essays on this theme has been recently collected by Parish $\mathrm{H}$. (ed.), Superstition and Magic in Early Modern Europe. A Reader (London - New Delhi New York - Sidney: 2015). See also essays by Irene Galandra Cooper, 220-243, and Katie Tycz in this volume, 244-271.

23 See Modica M., Infetta dottrina: inquisizione e quietismo nel Seicento (Rome: 2009).

24 Malena A., L'eresia dei perfetti. Inquisizione romana ed esperienze mistiche nel Seicento italiano (Rome: 2003).

25 On this act of censorship, see Caravale, Forbidden Prayer 191-223; and also Fragnito G., Proibito capire. La Chiesa e il volgare nella prima età moderna (Bologna: 2005); Fantini M.P., "Saggio per un catalogo bibliografico dai processi dell'Inquisizione: orazioni, scongiuri, libri di segreti (Modena 1571-1608)", Annali dell'Istituto storico italo-germanico in Trento 25 (1999) 587-668. 
conceived as part of a wider project of liturgical standardisation that soon proved problematic. It was unrealistic to think that the Church could control every private devotional space, every single local cult, every expression of piety practised by each individual or by each religious community, whether loosely or clearly defined (fraternities, companies, or other). The second reason for this difficulty of implementation was that the Church authorities who should have been rooting out hidden heterodox devotional manifestations were themselves deeply absorbed in both mystical culture and magic-superstitious culture. ${ }^{26}$ From the late sixteenth to the early seventeenth century, Rome moved increasingly openly towards the legitimisation of two channels of devotional expression. Establishing the boundaries of two devotional spheres, one private and one public, Rome made the same distinction that had been made in the mid-sixteenth century under the auspices of Nicodemian dissimulation. With its formal sanctioning, official status was given to the distinction, bringing it to some extent out into the open.

Among the most important passages of this Church policy was the decree on litanies issued by Pope Clement VIII in September 1601. Faced with the uncontrolled proliferation of new prayers, often containing 'inept, dangerous and erroneous' statements, the decree prohibited all litanies that were not contained in breviaries, missals, Roman pontificals and rituals that had already been approved by Rome. Anyone who dared publish new prayers or recite them publicly would incur the penalties established by the bishop and the inquisitor. By emphasising, as did the text of the decree, that public dissemination of prayers (through publication or even oral transmission) was the position that was most feared and would be most severely punished, the Roman authorities tacitly admitted the existence of a double regime, one which was clearly more tolerant of the private use of these same prayers. ${ }^{27}$ The editor responsible for the preparation of the first draft of the decree also tolerated existing collections of prayers for private use upon examination by ordinary bishops or by inquisitors. However, the proposal was not accepted in the final printed version of the decree. ${ }^{28}$

26 The work that remains fundamental on this issue is Thomas K., Religion and the Decline of Magic: Studies in Popular Beliefs in Sixteenth and Seventeenth Century England (New York: 1997 [first ed. London: 1971]). See also the points made by Burke P., Popular Culture in Early Modern Europe (New York: 1978); and more recently Bouza F., Corre manuscripto. Una historia cultural del Siglo de Oro (Madrid: 2001).

27 Caravale, Forbidden Prayer 181-182.

28 Ibid., 183. 
During these years, a similar debate took place a few hundred metres away from the seat of the Roman Inquisition between the members of a young Congregation of the Blessed called by the Pope to discuss and to approve devotions bestowed on those who had died in the odour of sanctity but who had not yet been canonised by Rome. Some argued that, in the name of custom and the preservation of local devotional traditions, all expressions of piety should be permitted. Others considered this position to be a capitulation by the Church authority. The compromise reached within the young Congregation, thanks especially to the mediation of two authoritative cardinals, Baronio and Bellarmino, was to authorise people to carry out, in private, devotional acts that were prohibited in public. In other words, people were allowed to worship men and women who had not yet been officially canonised by the Church in private, while it was forbidden in public. ${ }^{29}$ The aim of the compromise was to safeguard personal or communal devotional practices (in the sense of community of faith) rooted in worshippers' emotions, so long as these practices did not elicit public scandal. However, behind these measures, which drew a sharp distinction between private and public spheres of devotion, lay more than a fear of public scandal. Surviving documents that have emerged from the archives of the Roman Inquisition offer interesting insights into the cultural and mental attitude with which Clement viII promoted these measures. In his discussion of the problem of applying excessively strict censorial measures, the pontiff sought to reach a compromise between the harshness of current legislation and the obvious difficulties in its implementation. In particular, Roman censorial authorities were faced with the task of identifying and correcting all the forbidden books listed on the Index with the clause donec expurgatur, that is all those volumes that were prohibited until the authorities completed the work of 'cleaning' and correction. Clement viII suggested that the Congregation of the Index ask readers and sellers of suspect books to submit a full note of the titles held, leaving the Congregation the discretion of granting reading permission after having thoroughly verified the personal qualities of the applicant. ${ }^{30}$

But the pontiff's proposal was not limited to this. Clement VIII also proposed that readers should be allowed to keep forbidden books near their

29 See Gotor M., I beati del papa. Santità, Inquisizione e obbedienza in età moderna (Florence: 2002), and more recently Noyes R.S., "On the Fringes of Center: Disputed Hagiographic Imagery and the Crisis Over the Beati moderni in Rome ca. 160o", Renaissance Quarterly 64 (2011) 800-846. See also Dall'Aglio's essay in this volume, 386.

30 Reference is made to the proposal made in 1594 by Clemente vil in his Animadversiones; on this point, see Frajese V., Nascita dell'indice. La censura ecclesiastica dal Rinascimento alla Controriforma (Brescia: 2006) 155-156. 
person without reading them until the Index expurgatorius was published. ${ }^{31}$ This aimed to resolve the practical problems that the Roman policies of censorship faced at the end of the century. The Roman censorship machine was under serious strain due to economic problems and a lack of adequate staff. ${ }^{32}$ It was very difficult to prepare the material for the correction of individual volumes, and impossible to arrange for the preparation of newly corrected versions of thousands of copies of volumes awaiting their attention. It was thus better to leave the task of identifying individual volumes to readers and printers, and to oversee the correction of these same volumes as and when the censors provided detailed guidance. Ultimately, only the first of these two proposals was approved by the Congregation of the Index immediately. ${ }^{33}$

Regardless of the immediate success or not of his policies, Clement viII was to outline the direction that the censorial apparatus would take in the following decades. He declared worshippers responsible for their own devotional space. Between the moment of acquiring an offending volume and the moment of reading the text, the Pope identified a grey area in which worshippers and their consciences were the sole judges. Beneath these propositions lay a form of censorship based on a dual level of control (exterior/interior or public/ private). This transformed the reading of correctable books into an issue of personal conscience and internal judgement, in relation to which the inquisitorial authorities needed to take a step back. ${ }^{34}$ The pontiff's second proposal was only adopted into censorship practices a few years later when readers were invited, more or less formally, to personally correct the amendable forbidden

31 Reference is made to the Indicis librorum expurgandorum in studiosorum gratiam confecti Tomus primus. In quo quinqinginta auctorum libriprae coeteris desiderati emendatur per Fr. Jo. Mariam Brasichellen. Sacri Palatii Apostolici Magistrum in unum corpus redactus et publicae commoditati aeditus (Rome, ex Typographia R. Cam. Apost.: 1607). On the turbulent fortunes of this Index Expurgatorius, of which only fifty copies were printed in 1607 before being immediately suspended, see Fragnito G., "Aspetti e problemi della censura espurgatoria", in L'Inquisizione e gli storici. Un cantiere aperto, Atti del Convegno dell'Accademia Nazionale dei Lincei, Rome, 24-25 giugno 1999 (Rome: 2000) 161-178; Fragnito G., “«In questo vasto mare de libri prohibiti et sospesi tra tanti scogli di varietà et controversie»: la censura ecclesiastica tra la fine del Cinquecento e i primi del Seicento", in Stango C. (ed.), Censura ecclesiastica e cultura politica in Italia tra Cinquecento e Seicento (Florence: 2001) 1-35; now also in Fragnito G., Cinquecento italiano. Religione, cultura e potere dal Rinascimento alla Controriforma (Bologna: 2011) 325-364; Rebellato E., "Il miraggio dell'espurgazione. L'indice di Guanzelli del 1607", Società e storia $3^{1}$ (2008) 715-742.

Godman P., The Saint as Censor: Robert Bellarmine between Index and Inquisition (Leiden Boston: 2000).

33 Frajese V., "La politica dell'indice dal tridentino al clementino (1571-1596)", Archivio italiano di storia della pietà 11 (1998) 269-356, esp. 328; Frajese, Nascita dell'indice 156. 
books in their possession on the basis of the censorial instructions issued by Rome (except, of course, for books that were prohibited omnino). Anyone in possession of an amendable volume on the index (a volume condemned with the Latin formula donec expurgatur) should identify the names and places to be deleted - following instructions given by the Roman censors. They should personally attend to this censorship by striking the texts through with a line of ink or the stroke of a pen. Readers and printers therefore had to regulate themselves, learning to recognise (and apply) the limit beyond which their personal reading was dangerous and, therefore, punishable by the inquisitorial authorities. ${ }^{35}$ The absence of official Roman corrections relating to many of the books on the indices condemned with the words donec corrigantur made this practice much more difficult to achieve than had originally been imagined by Church leaders. In the Index Expurgatorius of 1607, the index that should have contained all the corrections approved by Rome to date, we find information relating to only fifty works, of a total of over three hundred amendable volumes. ${ }^{36}$ The attentiveness of some local censors and inquisitors could compensate for this weak system only a little.

The distinction between public and private devotional spheres, created in the mid-sixteenth century under the auspices of Nicodemism and understood as a way to evade increasing Church repression, was thus endorsed by Rome at the end of the century. The success of this appropriation is related to the particular manner in which Rome applied the distinction. On one hand, Rome allowed the existence of a private devotional sphere. But, on the other hand, Rome did not appreciate the idea that this private sphere be filled with ideas diverging from its own religious teaching, and thus strove to fill it with practices and doctrines true to Catholic orthodoxy and the Counter-Reformation project. Although the worst of the anti-Protestant struggle was over, the conditions that had led to the emergence of the distinction half a century earlier had not vanished. On the contrary, a dialectic between the pressure of external rules and the sphere of individual conscience had instead developed. As a consequence of the Protestant challenge and the repressive Roman response of the mid-sixteenth century, this tension fundamentally shaped Italian approaches to religious control. Once Rome had defeated the menace posed by Protestant doctrines circulating in the Italian peninsula, it introduced an ambitious project of religious and cultural discipline to control diverse areas of

35 For an introduction to this topic, see Savelli R., Censori e giuristi: storie di libri, di idee e di costumi (secoli XVI-XVII) (Milan: 2011); Cavarzere M., La prassi della censura dell'Italia del Seicento: tra repressione e mediazione (Rome: 2011).

$36 \quad$ See above, note 31. 
human knowledge and action. A project of this nature inevitably expanded the scope of this dialectical opposition. It is no coincidence that the decades bridging the sixteenth and seventeenth centuries are often referred to as the age of dissimulation par excellence, the age when the individual felt the pressing need to learn and master external appearances whilst concealing the inner space of the conscience from outer gaze in fields of politics and faith as well as morality. ${ }^{37}$ The increased pressure and external constraints that limited each individual went hand in hand with the construction of a private, physical and mental space, distinct from the public space, in which the individual could cultivate his or her own individual conscience. It was a process that could develop further and more fully in a society in which the dialectic between public and private spheres evolved from an association with specific situations in individual cases to a permanent structural element common to the whole culture. ${ }^{38}$

This cultural process is exemplified by libertine culture. Libertinism, a movement that has been called the anti-clericalism of the Counter-Reformation, took a valuable lesson from these external conditions. ${ }^{39}$ Libertinism was thus able to seize and conquer the sphere of the private conscience, a conscience that was inner, independent, secular and closed in on itself. One of the defining traits of seventeenth-century Italian libertine culture is the distance between the freedom of language, in terms of form and content, in private conversations from the (relative) moderation of language found in printed works. In other words, the freedom that was granted to libertine culture was filtered through the imposition (and acceptance) of the division between orality and writing, and between (collective) private and public spheres. What could be lawfully shared between people in the intimacy of a salon, could not be lawfully disclosed to the public in the press. ${ }^{40}$

At the end of the sixteenth century and start of the seventeenth, the ambiguity (and audacity) of the challenge thrown from Rome was to exploit the dialectic between external pressures and the inner space of conscience - that Rome had contributed decisively to forming - in order to construct a religious

37 Finally on this theme, see Snyder J.R., Dissimulation and the Culture of Secrecy in Early Modern Europe (Berkeley: 2009).

38 This movement consists of the semantic shifting between Nicodemism and dissimulation, starting from the mid-sixteenth century onwards.

39 For the definition used in the text cf. Spini G., Ricerca dei libertini: la teoria dell'impostura delle religioni nel Seicento italiano (Florence: 1983; I ed. 1950) 13.

40 On these aspects of libertine culture, see Pintard R., Le libertinage érudit dans la première moitié du XVII e siècle (Paris: 1943) 209-270, and above all Cavaillé J.-P., Dis/simulations: Jules-César Vanini, François La Mothe Le Vayer, Gabriel Naudé, Louis Machon et Torquato Accetto: religion, morale et politique auXVII ${ }^{e}$ siècle (Paris: 2002). 
and conformist individual conscience which opposed the autonomous and secular libertine conscience. It was to construct a kind of superego that was more royalist than the king, to construct a private individual conscience in which external conditions were observed better than they could be in the public sphere. The increasing role of confession in the post-Tridentine decades moved in this same direction. Even though the confessional was devised in the second half of the sixteenth century (in Borromean Milan) as an instrument of social discipline and control, a sort of open space where the behaviour of the penitent and the priest could be controlled from the outside, it did not alter the fact that the sacrament of confession was valued as a place of intimacy where secrets could be revealed and hidden outside the reach of the law (seen as an 'external forum') and a place that would allow the existence of legitimate secrets of the heart and mind ('internal forum'). ${ }^{41}$ By closely binding confession and the work of the Inquisition, or rather denying absolution to those who had not confessed their sins of heresy to an inquisitor, Rome transformed the conscience into a silent echo chamber of its own external rules and regulations. ${ }^{42}$ Even the widespread spontaneous appearances of worshippers before a judge of faith, which was strongly encouraged by ecclesiastical ranks during the seventeenth century as a form of self-denunciation of deviant behaviour, sought to make worshippers internalize the formal (public) prohibitions imposed on them by censorial and inquisitorial authorities. ${ }^{43}$

Rome thus tried to exploit one of the most typical features of the CounterReformation to its own advantage, a feature that it had contributed to creating: the division between private and public spheres that is implicit in every act of dissimulation. The result was inevitably ambivalent. In one way, worshippers' internalisation of prohibitions was key to the success of the cultural project of the Counter-Reformation. An example of this process is the caute lege, a clause first introduced in the 1606 Index issued by Brisighella, the Master of the Sacred

41 de Boer W., The Conquest of the Soul: Confession, Discipline, and Public Order in CounterReformation Milan (Leiden - Boston: 2001); Rittgers R.K., The Reformation of the Keys: Confession, Conscience, and Authority in Sixteenth-Century Germany (Cambridge, Ma. London: 2004).

42 On the topic of confession, see Tentler T.N., Sin and Confession on the Eve of the Reformation (Princeton, N.J.: 1977); Prosperi, Tribunali della coscienza; Rusconi R., L'ordine dei peccati: la confessione tra Medioevo ed età moderna (Bologna: 2002); Lavenia V., L'infamia e il perdono: tributi, pene e confessione nella teologia morale della prima età moderna (Bologna: 2004).

43 On spontaneous appearances before a judge of faith, see the useful remarks in Kermol E., La rete di Vulcano. Inquisizione, libri proibiti e libertini nel Friuli del Seicento (Trieste: 199o); and Visintin D., L'attività dell'inquisitore fra Giulio Missini in Friuli, 1645-1653: l'efficienza della normalità (Trieste: 2008). 
Palace, and subsequently adopted by many Spanish indices, which invited the Catholic reader to read certain volumes 'with caution'. This was an important step in assigning individual and collective responsibility to the reader, moving towards the internalisation of censorship measures by the reader, which was the longest-lasting and most productive result of inquisitorial action. The more or less explicitly set objectives of censorship - which were largely achieved - involved introducing doubt and scrupulousness as constant elements into daily relationships with books and transforming the reader into an accomplice and an informant. ${ }^{44}$ In other ways, however, the formalisation of a double regime allowed worshippers and the clergy to practise a double standard, in terms of their devotional practices. However, the freedom and protection that the private sphere afforded was not always interpreted with the rigor and sense of personal responsibility that Baronio and Bellarmino had demanded in private in the early seventeenth century with their strict control of devotional forms. ${ }^{45}$ There were those, even among ecclesiastical ranks, who took advantage of these spaces of freedom to carve out areas of deeply discordant behaviour away from the rigid external rules made public by Rome. In some cases, Rome could not intervene, in many others Rome did not want to intervene. There are many examples of the ambiguous stance taken by the ecclesiastical authorities towards libertines, who were guaranteed a certain level of impunity by their influential protectors on condition that they made a clear distinction between the public aspect of published works and the private realm of conversations between associates. In Rome, for example, a warm welcome was given to a group of 'déniasés d'Italie' led by Gabriel Naudé, a member of the Barberini family and librarian to Cardinal Guido da Bagni and Jean-Jacques Bouchard. In Venice, the Academy of the Unknowns (Accademia degli Incogniti) were protected by patrons and a network of relations that guaranteed them impunity and a peaceful life as long as they kept their discussions in an esoteric sphere and showed formal deference towards the precepts of the Church. ${ }^{46}$

Fundamentally, Rome knew that this double standard was necessary in order to consolidate the Catholic Church as an institution and for the success

44 See Peña M., Escribir y prohibir. Inquisición y censura en los Siglos de Oro (Madrid: 2015) 214-225; Fragnito G., "La colpa di leggere nella prima età moderna", in Dall'Olio G. Malena A. - Scaramella P. (eds.), Per Adriano Prosperi, vol. I: La fede degli italiani (Pisa: 2011) 171-182; Fragnito G., "Le letture sospette: prospettiva di ricerca sui controlli ecclesiastici”, in Vega M.J. - Nakládalová I. (eds.), Lectura y culpa en el siglo XVI. Reading and Guilt in the 16th Century (Bellaterra, Barcelona: 2012) 19-44.

45 Cf. Caravale, Forbidden Prayer 245-249.

46 Pintard, Le libertinage érudit 209-270; Cavarzere, La prassi della censura 224; Infelise M., I padroni del libro. Il controllo sulla stampa in età moderna (Rome - Bari: 2014) 141. 
of its attempts at control. For some, the double standard was a necessary price to pay. For others, it was a difficult element to eliminate in the extremely ambitious Counter-Reformation project: it was impossible to guarantee the total pervasiveness of its measures of control. For all, it was considered a price that could be quietly tolerated. One of the ways in which the censorship authorities institutionalised a mechanism of dispensation from rules otherwise presented as inflexible was the system of licentiae legendi ('reading permits'), devised to favour some individuals by exempting them from the need to observe bans on reading prohibited works. ${ }^{47}$

Such ambiguity did not escape the attention of the most perceptive external observers. In the early years of the seventeenth century, an English bishop put into sharp focus the separation between theory and practice, indeed, between appearance and reality, which characterised Italian religious life. In his Relation on the 'state of religion', the English bishop Edwin Sandys, who was stationed in the Italian peninsula, criticised the incurable rift between the Catholic doctrine taught in the 'schools' and the religious practices of worshippers. 'This religion', he wrote, 'seemeth notwithstanding at this day, not so corrupt in the very doctrine and in Their Schooles [...] as it is in the Practise thereof, and in the usage among Themselves'. ${ }^{48}$ The outer, public and formal face of the Church only corresponded partially with the private religion practised by the clergy and worshippers. Sandys' testimony was picked up two decades later by the famous Venetian jurist, Paolo Sarpi, who used it to fuel relentless anti-Roman controversy. In 1625, he translated and completed Sandys' Relation noting, among other things, the double standard implicit in many religious practices, first of all, in prayer: 'schools do not teach that prayer is pleasing to God only with the devotion of the heart; in practice, both public and private prayers are recited by voice only, and people think that they have satisfied their debt in

47 On this system and the controversies that surrounded its implementation, see Frajese V., "Le licenze di lettura tra vescovi e inquisitori. Aspetti della politica dell'Indice dopo il 1596", Società e storia 86 (1999) 767-818; Baldini U., "Il pubblico della scienza nei permessi di lettura dei libri proibiti delle Congregazioni del Sant'Uffizio e dell'Indice: verso una tipologia professionale e disciplinare", in Stango C. (ed.), Censura ecclesiastica e cultura 171-201.

48 A Relation of the state of religion: and with what Hopes and Policies it hath beene framed, and is maintained in the severall states of these western parts of the world (London, Printed for Simon Waterson dwelling in Paules Churchyard at the signe of the Crowne: 1605) fol. A3v. On this work, see Cozzi G., "Sir Edwin Sandys e la Relazione dello Stato della Religione", Rivista Storica italiana 79 (1967) 1095-1121, and more recently, Prosperi A., "Lo stato della religione tra l'Italia e il mondo: variazioni cinquecentesche sul tema”, Studi storici 56 (2015) 29-48. 
this way'. ${ }^{49} \mathrm{He}$ theorised that private devotion should remain separate in register and in intensity from public devotion, which should be practised with the heart and not lips. In practice, however, private devotion strongly resembled public devotion, which was mechanically recited out loud without any inner engagement. ${ }^{50}$ Of course, Sandy and Sarpi were biased observers, roused by a profound dissent from Rome and what Rome represented in terms of religious doctrine and earthly power. However, their observations were on target. The distance between school and practice, between appearance and reality, between public and private, was a feature of Counter-Reformation society and, fundamentally, we might suggest, of every system of power. Each of their own accord, the libertines on one hand, and the champions of orthodoxy on the other, tried to exploit this distance to their own advantage. Although following very different paths, both marked an important step in the arduous journey towards modernity.

\section{Bibliography}

Beccaria G., Sicuterat. Il latino di chi non lo sa: Bibbia e liturgia nell'italiano e nei dialetti (Milan: 1999).

Bouza F., Corre manuscripto. Una historia cultural del Siglo de Oro (Madrid: 2001).

Burke P., Popular Culture in Early Modern Europe (New York: 1978).

Cameron E., Enchanted Europe: Superstition, Reason, and Religion 1250-1750 (Oxford: 2010).

Caravale G., Forbidden Prayer: Church, Censorship and Devotional Literature in Renaissance Italy (Farnham: 2012).

Cavaillé J.-P., Dis/simulations: Jules-César Vanini, François La Mothe Le Vayer, Gabriel Naudé, Louis Machon et Torquato Accetto: religion, morale et politique au XVIIe siècle (Paris: 2002).

Cavarzere M., La prassi della censura dell'Italia del Seicento: tra repressione e mediazione (Rome: 2011).

Cozzi G., "Sir Edwin Sandys e la Relazione dello Stato della Religione", Rivista Storica italiana 79 (1967) 1095-1121.

49 Relazione dello stato della Religione, e con quali dissegni et arti ella è stata fabricata e maneggiata in diversi stati di queste occidentali parti del mondo, in Sarpi P., Lettere a Gallicani e Protestanti, Relazione dello Stato della Religione, Trattato delle materie beneficiarie, eds. G. and L. Cozzi (Turin: 1978) 51-88 (56); Caravale, Forbidden Prayer 239.

5o On this topic, see the significant works by Beccaria G., Sicuterat. Il latino di chi non lo sa: Bibbia e liturgia nell'italiano e nei dialetti (Milan: 1999), and Waquet F., Latin, or, The Empire of the Sign: From the Sixteenth to the Twentieth Century (London; New York: 2001). 
de Boer W., The Conquest of the Soul: Confession, Discipline, and Public Order in CounterReformation Milan (Leiden - Boston: 2001).

Del Soldato E., Simone Porzio. Un aristotelico tra natura e grazia (Rome: 2010).

Fragnito G., Cinquecento italiano. Religione, cultura e potere dal Rinascimento alla Controriforma (Bologna: 2011).

Fragnito G., "Le letture sospette: prospettiva di ricerca sui controlli ecclesiastici", in Vega M.J. - Nakládalová I. (eds.), Lectura y culpa en el siglo XVI. Reading and Guilt in the 16th Century (Bellaterra, Barcelona: 2012) 19-44.

Fragnito G., Proibito capire. La Chiesa e il volgare nella prima età moderna (Bologna: 2005).

Frajese V., Nascita dell'indice. La censura ecclesiastica dal Rinascimento alla Controriforma (Brescia: 2006).

Godman P., The Saint as Censor: Robert Bellarmine between Index and Inquisition (Leiden - Boston: 2000).

Infelise M., I padroni del libro. Il controllo sulla stampa in età moderna (Rome - Bari: 2014).

Jacobson Schutte A., Aspiring saints: Pretense of Holiness, Inquisition, and Gender in the Republic of Venice, 1618-1750 (Baltimore, Md.: 2001).

Kermol E., La rete di Vulcano. Inquisizione, libri proibiti e libertini nel Friuli del Seicento (Trieste: 1990).

Malena A., L'eresia dei perfetti. Inquisizione romana ed esperienze mistiche nel Seicento italiano (Rome: 2003).

Modica M., Infetta dottrina: inquisizione e quietismo nel Seicento (Rome: 2009).

Novi Chavarria E., Monache e gentildonne: un labile confine. Poteri politici e identità religiose nei monasteri napoletani: secoli XVI-XVII (Milan: 2001).

Noyes R.S., "On the Fringes of Center: Disputed Hagiographic Imagery and the Crisis Over the Beati moderni in Rome ca. 16oo", Renaissance Quarterly 64 (2011) 800-846.

Parish H. (ed.), Superstition and Magic in Early Modern Europe. A Reader (London New Delhi - New York - Sidney: 2015).

Peña M., Escribir y prohibir. Inquisición y censura en los Siglos de Oro (Madrid: 2015).

Petrocchi M., Storia della spiritualità italiana, vol. I: Il Duecento, il Trecento e il Quattrocento (Rome: 1978).

Pintard R., Le libertinage érudit dans la première moité du XVII e siècle (Paris: 1943).

Prosperi A., Tribunali della coscienza. Inquisitori, confessori, missionari (Turin: 1996).

Rittgers R.K., The Reformation of the Keys: Confession, Conscience, and Authority in Sixteenth-Century Germany (Cambridge, Ma. - London: 2004).

Savelli R., Censori e giuristi: storie di libri, di idee e di costumi (secoli XVI-XVII) (Milan: 2011). 
Sluhovsky M., Believe Not Every Spirit: Possession, Mysticism, \& Discernment in Early Modern Catholicism (Chicago: 2007).

Snyder J.R., Dissimulation and the Culture of Secrecy in Early Modern Europe (Berkeley: 2009).

Tentler T.N., Sin and Confession on the Eve of the Reformation (Princeton, N.J.: 1977).

Thomas K., Religion and the Decline of Magic: Studies in Popular Beliefs in Sixteenth and Seventeenth Century England (New York: 1997 [first ed. London: 1971]).

Visintin D., L'attività dell'inquisitore fra Giulio Missini in Friuli, 1645-1653: l'efficienza della normalità (Trieste: 2008).

Waquet F., Latin, or, The Empire of the Sign: From the Sixteenth to the Twentieth Century (London; New York: 2001). 